\title{
An Update of Neuroendocrine Tumors of the Female Reproductive System
}

\author{
Mehmet KEFELi', Alp USUBÜTÜN ${ }^{2}$ \\ Department of Pathology, 'Ondokuz Mayıs University Faculty of Medicine, SAMSUN, TURKEY, ${ }^{2}$ Hacettepe University Faculty of Medicine, ANKARA, TURKEY
}

\begin{abstract}
Endocrine disease related tumors of female reproductive system mostly seen in ovary. Hormone producing ovarian tumors, ovarian tumor with functioning stroma, tumor related paraneoplastic and paraendocrine syndromes, paraganglioma and neuroendocrine tumors may include in this category. These tumors or its stroma can produce some hormones, which are led to endocrine manifestations. Rarely tumors associated with paraneoplastic and endocrine syndromes. Among these lesions, primary neuroendocrine tumors are rarely seen in the gynecologic tract, comprising $2 \%$ of gynecologic cancers. They have specific cytological and histopathological features that are usually helpful in differentiating them from epithelial tumors. Nevertheless, they still provide a diagnostic and clinical challenge, given their rarity. Accurate diagnosis of neuroendocrine tumor is essential for both therapeutic and prognostic purposes. In this review, we focused on neuroendocrine tumors of the gynecological tract and their morphological, immunohistochemical and molecular findings. In addition, we will briefly discuss paraganglioma and other endocrine diseases related tumors in the gynecological tract.
\end{abstract}

Key Words: Neuroendocrine tumors, Female genital neoplasms, Paraganglioma, Neuroendocrine cells, Immunohistochemistry

\section{INTRODUCTION}

Endocrine disease related tumors of female reproductive system are mostly seen in the ovary and typically include hormone producing ovarian tumors, ovarian tumor with functioning stroma, tumor related paraneoplastic and paraendocrine syndromes, paraganglioma and neuroendocrine tumors (NETs). Primary NETs rarely seen in the female reproductive system and create a clinical and diagnostic challenges because of their rarity. In this review, we are focusing on NETs of the female reproductive system along with their morphological, immunohistochemical and molecular findings. In addition, we will briefly discuss paraganglioma and other endocrine diseases related tumors in the gynecological tract.

\section{PARAGANGLIOMA}

Paragangliomas are tumors arising from paraganglia, which composed of neural-crest derived neuroendocrine cells associated with symphathetic and parasympathetic nerves. Symphatetic paraganglioma arise sympathetic chains along the paravertebral axis and sympathetic nerve branches in pelvic organs and retroperitoneum. Parasympathetic paraganglioma arise mainly from branches vagus and glossopharyngeal nerves in head and neck region (1-3). Paragangliomas rarely seen outside the usual location and a few cases has been reported from the ovaries, uterus, vagina

(Turk Patoloji Derg 2015, 31(Suppl):128-144)

Received : 01.06.2015 Accepted : 02.06.2015 and vulva (4-9). Among these locations, ovarian tumor has a different clinical significance. Two out of 6 reported cases of ovarian paraganglioma behaved aggressively, one exhibiting lymph node metastasis and the other infiltrating the uterus. Both malignant cases were large, measuring 9 and $8 \mathrm{~cm}$, respectively. Moreover, one case was positive with inhibin and other case positive with inhibin and calretinin. This staining result could be diagnostic pitfall for sex cord- stromal and steroid cell neoplasms, which would be expected to be positive with both markers (9).

Clinically, because of paragangliomas can be secreted catecholamine, some cases had hypertension or other manifestations related to catecholamine hypersecretion. Morphologically, tumors generally show classical pattern; small nests ('zellballen') of neuroendocrine cells with interspersed small blood vessels. Syncytial-like growth, diffuse pattern, spindle cells and extreme cytological atypia may also be observed. Immunohistochemically, tumors are usually positive with general neuroendocrine markers and tyrosine hydroxylase (except of some parasymphatetic paraganglioma), and negative with cytokeratins (except of some cauda equine paraganglioma). S100 protein demonstrates the sustentacular cells network. It is of note that loss of SDHB expression is important to triage patient with familial paraganglioma syndromes caused by $S D H x$ mutations. Additionally, use of SDHB antibody

Correspondence: Mehmet KEFELİ

Ondokuz Mayıs Üniversitesi Tip Fakültesi, Patoloji Anabilim Dalı

SAMSUN, TURKEY

E-mail: mehmetkefeli@gmail.com Phone: +90 3623121919 
also provides prognostic information of tumor, because of the high rate of malignancy associated with $S D H B$ related paragangliomas (1-3). There has not been reported $S D H x$ related familial paraganglioma in female reproductive system yet.

\section{HORMONE PRODUCING OVARIAN TUMORS}

Hormones producing ovarian tumors are generally arising from ovarian cortical and hilar cells, and classified as sex cord-stromal tumors. These cells as condensations of subcoelomic mesenchyme during the embryogenesis, and then differentiated into the supporting stroma of the cortex and granulosa-theca cells of the developing follicle in the adult ovary. Granulosa-stromal cell tumors, Sertolistromal cell tumors and steroid cell tumors compromise this group. Hyperestrinizm or hyperandrogenism related symptoms are relatively common in this group of neoplasms due to excess estrogen or androgen production. Other less common ovarian neoplasms that may have endocrine manifestations include germ cell tumors (e.g. choriocarcinoma, dysgerminoma) producing of chorionic gonadotropin, and monodermal teratoma (struma ovarii) that can sometimes present with hyperthyroidism (10).

\section{TUMORS WITH FUNCTIONING STROMA}

Ovarian tumor with functional stroma (OTFS) firstly highlighted by Dr. Scully and described as tumors exhibiting a specialized stroma, which are morphologically compatible with steroid hormone secretion. They are different than sex cord-stromal and steroid cell tumors. These tumors have also clinical, biochemical or pathological findings of endocrine function (11-13). Functioning stroma could be found in primary benign or malignant tumor, and also metastatic tumors of the ovary such as Krukenberg tumor as well $(11,14)$. Among epithelial tumors, mucinous tumors frequently contain a functioning stroma $(15,16)$. Most patients with OTFS are asymptomatic and have only laboratory evidence of increased steroid hormone secretion. However, in the absence of exogenous hormone replacement postmenauposal patients with OTFS may present with proliferative or hyperplastic endometrium, abnormal vaginal bleeding, or estrogenic effect in the vaginal cytology. In such cases, subsequent biochemical workup often reveals an excess serum estrogen level. Some patients may be associated with endocrine manifestation of estrogenic, androgenic, progestagenic, or a mixed profile. It is of note that neoplastic cells may have also aromatase activities that have capacity to convert androgen to estrogens $(15,17)$. While some tumors secret chorionic gonadotropin to luteinize stromal cells and promote hormone secretion, others cause mechanically progressive compression of graafian follicule leading to mechanical pressure of stroma and result in release of hormones. Tumors with synctiotrophoblast cells (e.g. dysgerminoma with syncytiotrophoblast giant cells) have been considered in this category owing to chorionic gonadotropin secretion. Microscopically, a functional stroma of the tumor may be adjacent to the ovarian stroma or its own stroma derived from the ovarian stroma, or combination of both. Stromal cells may resemble theca externa cells, theca lutein cells or combination. Stromal luteinization or stromal Leydig cell differentiation may also occur $(11,13)$.

\section{PARANEOPLASTIC AND PARAENDOCRINE SYNDROMES ASSOCIATED WITH OVARIAN TUMORS}

Paraneoplastic or paraendocrine syndromes may be the first sign of epithelial or other types of ovarian tumors. The underlying mechanisms of most paraneoplastic syndromes are not well elucidated; however, ectopic hormone secretion was typically linked to paraendocrine syndromes (Table I). While the most common paraneoplastic syndrome is subacute cerebellar degeneration that is found in up to $37 \%$ of all patients with ovarian cancer, hypercalcemia due to inappropriate secretion of parathyroid related peptide (PTHrp)

Table I: Paraneoplastic and paraendocrine syndromes related with ovarian tumors

\begin{tabular}{|l|}
\hline Paraneoplastic syndromes \\
\hline Subacute cerebellar degeneration \\
\hline Limbic encephalitis \\
\hline Polyneuritis \\
\hline Dermatomyositis \\
\hline Autoimmune hemolytic anemia \\
\hline Thrombotic disorders \\
\hline Nephrotic syndromes \\
\hline Cutaneous disorders \\
\hline Palmar fasciitis \\
\hline Rheumatoid arthritis \\
\hline Scleroderma \\
\hline Systemic lupus Erythematosus \\
\hline Paraendocrine syndromes and responsible hormones \\
\hline Hypercalcemia - Parathyroid hormone-related peptide \\
\hline Cushing's syndrome - Corticotropin-releasing factor \\
\hline Zollinger-Ellison syndrome - Gastrin \\
\hline Hypoglycemia - Insulin or proinsulin \\
\hline Hypertension - Renin or aldosterone \\
\hline
\end{tabular}


is the most common paraendocrine syndromes associated with ovarian tumors. Hypercalcemia has been typically described in two-thirds of patients with small cell carcinoma, hypercalcaemic type (small cell carcinoma-HT) (18-20).

\section{NEUROENDOCRINE TUMORS}

Neuroendocrine tumors are rarely encountered in the gynecologic tract; comprising approximately $2 \%$ of all gynecological tumors. While most occur in the cervix, they can also arise from other sites including vulva, vagina, uterus, and ovary $(10,21)$.

\section{Morphological Diagnosis}

Morphologically, well-differentiated NETs have characteristic organoid arrangements of the tumor cells, with solid, nested, trabecular, insular, psuedoglandular or mixed patterns. The cells are relatively small uniform shape and have regular round to oval nuclei with granular chromatin pattern ('salt and pepper' appearance), variable from pale to moderate eosinophilic, slightly granular cytoplasm. Poorly differentiated neuroendocrine carcinoma (large cell and small cell carcinomas) are high-grade malignancies with pleomorphism, necrosis, frequent mitotic activity exceeding 10 mitoses per 10 high power fields and Ki-67 (MIB-1) labeling index (10). While most NETs can be recognized on routine $\mathrm{H} \& \mathrm{E}$ sections, immunohistochemistry is required to confirm the diagnosis as well as to provide prognostic and predictive information.

\section{Immunohistochemical Diagnosis}

Immunohistochemically, neuroendocrine differentiation can be demonstrated with neuroendocrine markers such as chromogranins (chromogranin-A, -B, and -C), synaptophysin, CD56, CD57, neuron specific enolase, protein gene product 9.5 (PGP 9.5) and synaptic vesicle protein 2 (SV2). These markers recognize antigens that are expressed independently of the specific hormones secreted by neuroendocrine cells. However, not all of the previously listed markers are specific to NETs. Chromogranin-A, synaptophysin and CD56 are the most commonly used neuroendocrine markers in most practices. The demonstration of chromogranin positivity is diagnostic of a neuroendocrine tumor. Most laboratories use antibodies against chromogranin-A; however, some tumors express selectively other chromogranins (e.g. chromogranin-B). Furthermore, poorly differentiated neuroendocrine carcinomas can be negative or, focally or weakly positive for chromogranin-A. It is therefore important to justify the neuroendocrine differentiation by integrating synaptophysin into a panel $(22,23)$.
Many NETs typically express wide spectrum cytokeratin (CK), especially low molecular weight CKs (CK8 and CK18). CK immunoreactivity is usually seen as dot-like pattern, which is attributable to perinuclear accumulations of intermediate filaments. In some instance, CK can be useful for the differential diagnosis of primary site of NETs. For example, Merkel cell carcinomas (MCC) frequently express CK20, while this marker is typically absent or only focally expressed in most other high grade neuroendocrine carcinomas. Additionally, CKs are also important in the distinction of NETs from paragangliomas. When CK is negative in a NET, the tumor should be stained for tyrosine hydroxylase, which is the rate limiting enzyme in the catecholamine synthesis (2). Positivity for tyrosine hydroxylase helps diagnostician to render the diagnosis of paraganglioma. However, it must be noted that both chromogranin-A and tyrosine hydroxylase tends to be weak or negative in parasympathetic paragangliomas than in their sympathoadrenal counterparts (1-3, 22-25).

A variety of peptides can also could be secreted from NETs, including calcitonin, gastrin, serotonin, substance $\mathrm{P}$, vasoactive intestinal peptide, insulin, glucagon, somatostatin, catecholamines, parathyroid hormones, PTHrp, and etc. The identification of peptide profile of a NET is of clinical significance since this may serve as a biochemical screening tool (22).

Immunohistochemical markers are also used to determine a primary location of NET. Organ related markers used for this such as thyroid transcription factor-1 (TTF-1) for the thyroid and lung, ISL-1 and PDX-1 for pancreas, PAX8 for the thyroid, and CDX-2 and villin for the gastrointestinal tract. Positivity for SF-1 can serve a diagnostic marker for steroid hormone producing neoplasms; however, tumors originating from the adrenal gland or ectopic adrenal tissue in the gynecological tract also express SF-1. SF-1 gene regulates steroidogenesis, sexual differentiation, and gonadal and adrenal gland development and thought to regulate the inhibin gene as well. In this setting, the role of inhibin is similar to SF-1. However, it has to be noted that SF-1 has been reported to be more sensitive and more frequently positive than inhibin in the diagnosis of sex cordstromal tumors. Although no single marker can be used to ascertain the gynecological origin of NETs, p16 positivity is regarded a common finding in almost all cervical NETs. In addition, the role of HPV in the tumorigenesis of such proliferations is important to confirm of the cervical origin of NETs. The demonstration of Merkel cell Polyoma virus in a vulvar neuroendocrine carcinoma suggests a MCC in addition to paranuclear dot-like CK20 staining. Over 70\% 
MCC as granular nuclear positive with Merkel cell Polyoma virus antibody, which is a specific test for MCC; no other tumors are positive $(13,22,26)$.

\section{NEUROENDOCRINE TUMORS OF THE VULVA}

Primary cutaneous neuroendocrine carcinoma, also known as Merkel cell carcinoma (MCC), is an uncommon skin tumor. These tumors originate from small neuroendocrine cells of the lower epidermis. They are usually seen in sun exposed areas like the head and neck region in the elderly and/or immunosuppressed patients (27). The Merkel cell polyoma virus is concerned in the pathogenesis of this tumor (28). Primarily vulvar MCC is rarely seen. Tang et al. first described it and less than twenty cases have been reported to date $(29,30)$. Clinically, it is a highly aggressive tumor and often present with local recurrence or systemic dissemination.

MCC has several architectural patterns, namely trabecular, diffuse, solid and organoid. The neoplastic cells consist of dyscohesive cells with indistinct cell border along with small and oval-round nuclei, finely granular chromatin and scanty cytoplasm. Mitotic figures and apoptotic bodies are frequent. Immunohistochemistry is important to confirm the diagnosis. Tumor cells are positive for markers of neuroendocrine differentiation such as chromogranin-A, synaptophysin, CD56 and some peptide hormones such as calcitonin, somatostatin, vasoactive intestinal peptide, and neurofilament protein. They are also positive for some epithelial markers such as low molecular weight cytokeratin (CAM5.2), EMA, pancytokeratin and cytokeratin 20, the last typically staining in a dot-like paranuclear pattern, and are usually negative for vimentin, TTF-1 and S-100 (26, 31-33). Merkel cell Polyoma virus antibody is most specific marker for this tumor.

Melanoma, lymphoma, rhabdomyosarcoma, monophasic synovial sarcoma, poorly differentiated squamous cell carcinoma, neuroblastoma, primitive neuroectodermal tumor (PNET), eccrine carcinoma and metastatic neuroendocrine carcinoma must be included in the differential diagnosis of vulvar MCC.

Varying genetic alterations have been described MCC such as trisomies $(1,3 q, 5 p, 6)$, chromosomal losses $(3 p, 4,5 q, 7$, $10,14)$, L-myc amplification, increased VEGF expression, Bif-1 expression, mutation of PDGFR-alpha gene etc. One particular gene or oncogene has not been recognized as a main player in pathogenesis. However, it has to be noted that the Merkel Cell polyoma virus play important role and virus sequenced in up to $80 \%$ of tumors by polymerase chain reaction $(26,34)$.
There are also three reported cases of primary clear cell carcinoid tumor of the vulva with benign behavior (35).

\section{NEUROENDOCRINE TUMORS OF THE VAGINA}

Primary NETs are extremely rarely seen in the vagina. Most of these neoplasms are poorly differentiated neuroendocrine carcinomas, small cell type, and are indistinguishable from those identified in other anatomic site. These neoplasms tend to present with vaginal bleeding in postmenopausal patients with a mean age of 59 years $(36,37)$. A case was associated with ectopic Cushing's syndrome (38). A grossly, friable, exophytic mass is usually seen in the vagina. Microscopically, the tumor is composed of a sheet or tightly packed, small, round-oval cells with hyperchromatic nuclei with inconspicuous nucleoli. The cytoplasm is scant. Immunohistochemically, the tumor cells are positive for the usual neuroendocrine markers but negative for $\mathrm{p} 63$, the latter being important in the distinction from poorly differentiated squamous carcinoma. Small cell carcinoma of the vagina usually behaves aggressively with spread beyond the vagina at the time of diagnosis $(36,39,40)$.

\section{NEUROENDOCRINE TUMORS OF THE CERVIX}

NETs of the cervix may arise from the cells containing neuroendocrine granules that are seen in normal cervices or from the cervical reserve or stem cells $(41,42)$. These tumors are classified as typical carcinoid tumor (well differentiated NET with low grade features), atypical carcinoid tumor (well differentiated NET with intermediate grade features), small cell carcinoma (poorly differentiated neuroendocrine carcinoma, small cell type) and large cell (poorly differentiated neuroendocrine carcinoma, large cell type) neuroendocrine carcinoma (10). Genomic alterations caused by an HPV infection are the leading causes of these neoplasms. Up to $90 \%$ of neuroendocrine carcinomas of the cervix have been associated with HPV, most frequently type $18(43,44)$.

\section{A. Typical Carcinoid Tumor (Well Differentiated NET with Low Grade Changes)}

This is an extremely rare tumor in the cervix. Because of the rarity of this tumor, metastatic well differentiated NETs should always be excluded before final diagnosis. Carcinoid tumor usually has organoid appearance and shares similar features with other carcinoid tumors seen in different organs. The tumor frequently displays trabecular, acinar or nodular growth patterns and/or a rosette-like formation. The nuclei are round to oval and the chromatin is finely granular. Cytological atypia is usually minimal and mitosis is not present or is less than 2 per 10 high power fields (HPF). Unlike to other NETs, necrosis is not observed $(31,45)$ (Figure 1A,B). 

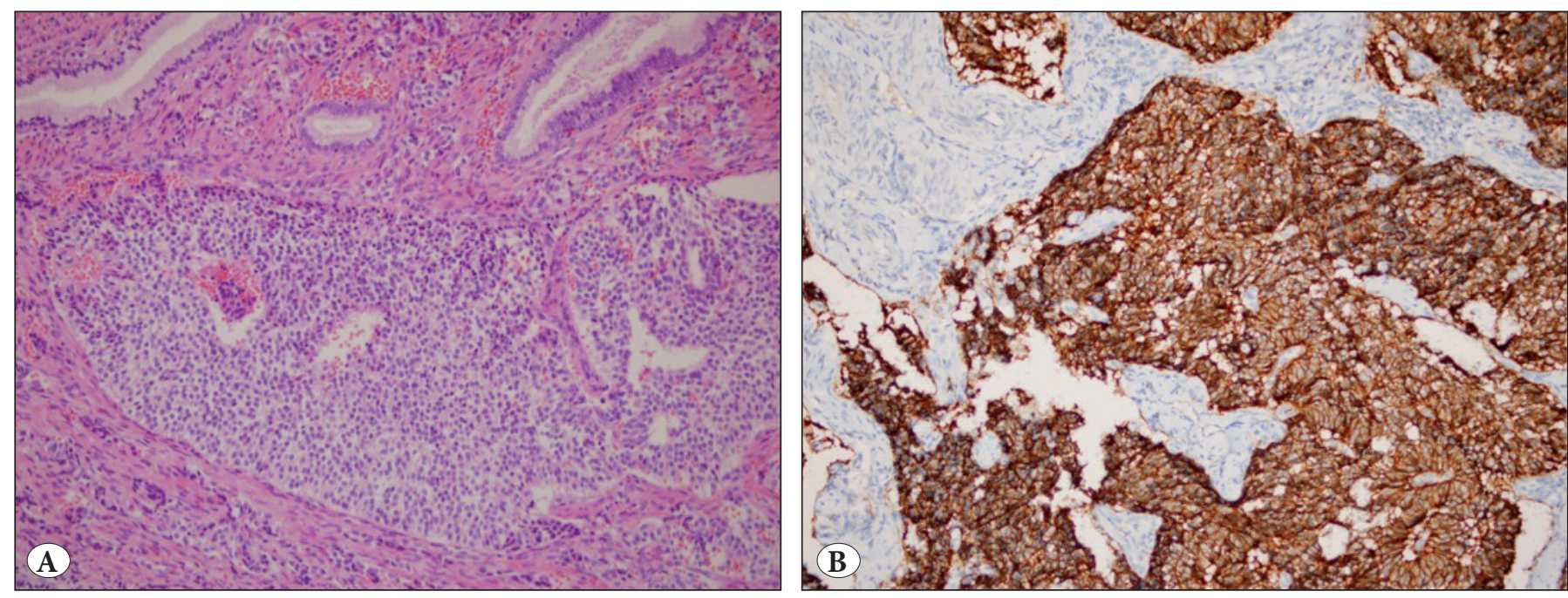

Figure 1: A) Carcinoid tumor of the cervix; neoplastic cells with minimal cytologic atypia and without mitosis (H\&E, $\mathrm{x} 200)$. B) Diffuse synaptophysin positivity (DAB; x200).

\section{B. Atypical Carcinoid Tumor (Well Differentiated NET with Intermediate Grade Features)}

Atypical carcinoid tumor is also rarely seen in the cervix with less than 15 cases that have been described. They are distinguished from typical carcinoid tumors by necrosis and mitotic count. Atypical carcinoid tumor has mild to moderate cytological atypia in association with a mitotic activity ranging from 2 to 10 mitoses per $10 \mathrm{HPF}$. Small foci of necrosis are often noted. These neoplasms often show lymphatic and/or vascular invasion leading to regional or systemic spread, respectively. Carcinoid syndrome due excess serotonin has been encountered in patients with distant metastatic disease (45-47).

\section{Small Cell Carcinoma (Poorly Differentiated Neuroendocrine Carcinoma, Small Cell Type)}

Small cell carcinoma is the most common NET of the cervix, and accounts for approximately $1-6 \%$ of all cervical carcinomas (1). Histologically, it is identical to its counterparts at other sites. Patients' ages range from 22 to 87 years (average age of 42 years). These neoplasms are typically identified in a younger age group comparing to patients with cervical squamous cell carcinoma $(31,48)$. Patients usually present with vaginal bleeding. Biochemical abnormalities and paraneoplastic syndromes such as Cushing syndrome, carcinoid syndrome and hypoglycemia have been rarely described in this setting $(49,50)$. The coexistence of small cell carcinoma with other epithelial tumors such as endocervical adenocarcinoma, adenocarcinoma in situ and squamous cell carcinoma may also occur $(49,51)$.
Grossly, the tumors range from small, invisible lesions to large ulcerated masses measuring up to $10 \mathrm{~cm}$ in diameter. They are more frequently deeply infiltrative than epithelial tumors of the cervix leading to a barrel-shaped appearance in most cases $(31,52)$. Microscopically, they are composed of small, oval-spindle cells, which are arranged like a sheet, trabecular or nested pattern. Rosette-like or acinar formation may be seen. The cells have high nuclear to cytoplasmic ratio, scanty cytoplasm, and hyperchromatic nuclei along with inconspicuous nucleoli. Nuclear moldings are common. Mitotic figures are numerous with karyorrhectic debris. Crush artifact, nuclear fragmentation ('hematoxylin bodies') and necrosis are frequent. Lymphatic and/or vascular invasion are often identified. The mitotic activity is frequent (>10 mitoses / $10 \mathrm{HPF}$ ). Geographic and comedo-necrosis are frequent (Figure 2A,B). Small foci of squamous and/or glandular differentiation can be seen but they usually be less than $5-10 \%$ of the total volume of the tumor $(32,48,53)$.

Immunohistochemically, tumor cells are positive for pankeratin, EMA, CEA, p16 and general neuroendocrine markers. It is of note that the rate of positivity for these markers varies from one study to another one. For example, chromogranin-A positivity has been reported between $32 \%$ and $76 \%$, whereas synaptophysin positivity has been reported between $50 \%$ and $90 \%$ of these neoplasms $(31,52,54,55)$. Therefore, multiple neuroendocrine markers, such as chromogranin-A, synaptophysin and CD56 must be used together as diagnostic tools.

Since small cell carcinoma is rare in the cervix, metastasis must be excluded. Metastatic carcinomas of the cervix are often seen as widely metastatic disease with multiple 

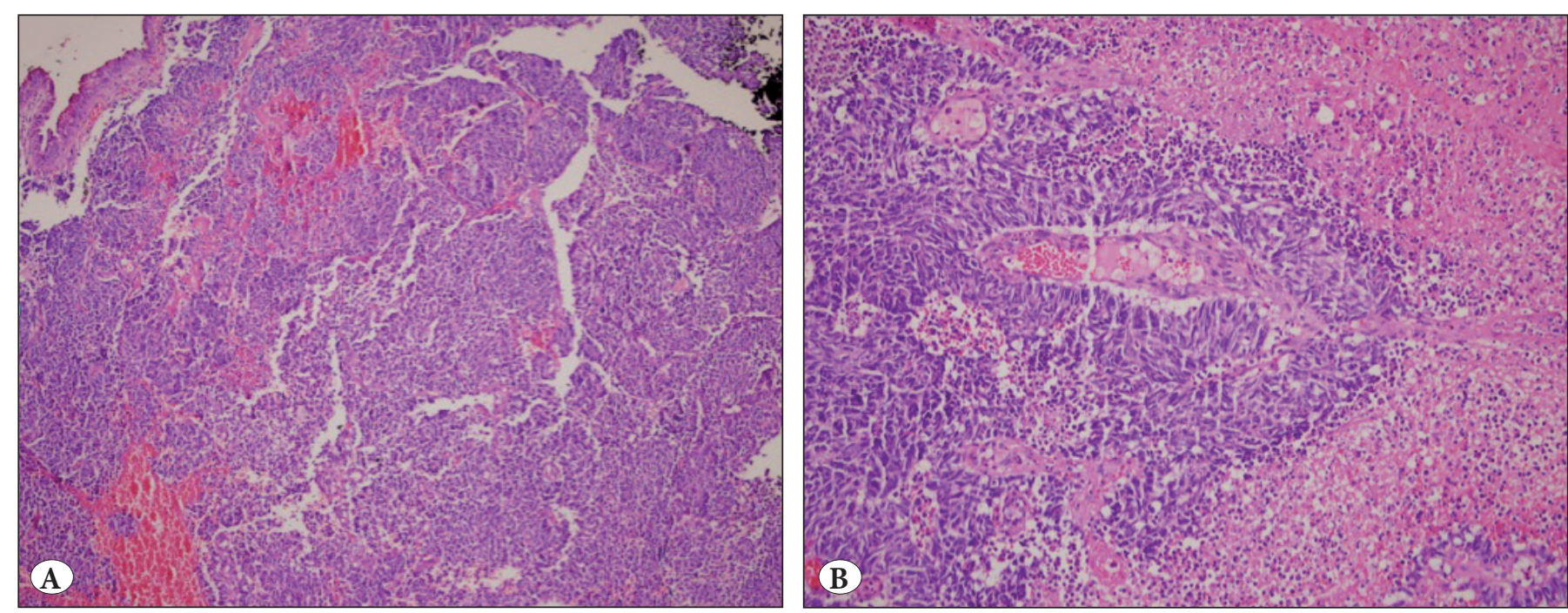

Figure 2: A) Small cell carcinoma of the cervix (H\&E, x100). B) Small oval to spindle tumor cells with scanty cytoplasm, and hyperchromatic nuclei with inconspicuous nucleoli associated with necrosis (H\&E, x200).

metastatic foci in other organs. The lung is a common organ for metastatic origin. Although TTF-1 is commonly found in small cell carcinoma of the lung, it is also variably positive in any high grade (poorly differentiated) neuroendocrine carcinomas including those arising from the cervix (56). P16 is also not specific marker for cervical primary. However HPV identification could be valuable for cervical origin. Small cell carcinoma should also be distinguished from small cell type of non-keratinizing squamous cell carcinoma, basaloid squamous cell carcinoma, lymphoma and melanoma. Squamous cell carcinoma is usually seen in elderly patients, and has at least focal squamous differentiation, and lacks nuclear molding and crush artifacts. Immunohistochemistry may be helpful in this distinction. CD56, synaptophysin and chromogranin are useful for detection of the neuroendocrine nature of the tumor, and p63 serves a valuable marker to identify squamous differentiation. Lymphoma and melanoma may rarely involve the cervix. Immunohistochemically, lymphoma (leukocyte common antigen, B-cell and T-cell markers) and melanoma (HMB-45, Melan-A and S-100) markers are helpful in distinguishing them from small cell carcinomas.

Small cell carcinomas of the cervix are highly aggressive neoplasms. Tumors have a tendency to metastasize early and widely. The prognosis is generally poor, even in patients diagnosed at the early stage $(57,58)$.

\section{Large Cell Neuroendocrine Carcinoma (Poorly} Differentiated Neuroendocrine Carcinoma, Large Cell Type)

Large cell neuroendocrine carcinoma (LCNEC) is a rare, poorly differentiated neuroendocrine neoplasm. They are highly aggressive and generally have a poor outcome, as do small cell carcinomas of the cervix (42). They are comprised of tumor cells that have abundant cytoplasm, large-vesicular high grade nuclei with prominent nucleoli. The tumor cells are organized as sheet-like, insular or trabecular patterns. The mitotic activity is frequent ( $>10$ mitoses / $10 \mathrm{HPF}$ ) and geographic necrosis is commonly seen (59). LCNECs usually have a focal glandular differentiation. In addition, they may be associated with glandular proliferations (adenocarcinoma in situ and invasive adenocarcinoma) $(42,60)$.

Small cell carcinoma, atypical carcinoid tumor, poorly differentiated squamous cell carcinoma and adenocarcinoma can mimic LCNEC. The tumor cells in squamous cell carcinoma have scanty cytoplasm and hyperchromatic nuclei with inconspicuous nucleoli. Atypical carcinoid tumors usually have less than 10 mitoses per $10 \mathrm{HPF}$, no extensive necrosis and high grade cytological atypia. Indeed, the tumor pattern is important for differential diagnosis from poorly differentiated adenocarcinoma; a trabecular and insular pattern are much more commonly seen in LCNEC. Geographic necrosis, vascular invasion, relatively uniform cytological features, numerous mitoses and apoptotic bodies are more common in LCNEC. Immunohistochemical markers (chromogranin-A, synaptophysin, CD56) may assist in this distinction, but it should be remembered that occasional cervical adenocarcinomas and adenosquamous carcinomas could be focally positive for neuroendocrine markers, which is often considered a focal divergent neuroendocrine differentiation (42). Poorly differentiated squamous cell 
carcinoma has at least focal squamous differentiation, keratinizing and intercellular bridges (Figure 3A-H).

While HPV infection plays major role in the pathogenesis of neuroendocrine tumors of cervix, other frequent molecular changes have also been detected. Loss of heterozygosity $(\mathrm{LOH})$ in any region of the short arm of chromosome 3 (3p14-p21, 3p21 or 3p22-p24) (47\%) and 9p21 (43\%) have been reported in NETs of the cervix. Low frequencies of $\mathrm{LOH}$ at the TP53 gene locus (17p13) and $R B$ gene locus (13q14) were identified, consistent with HPV-mediated inactivation of their protein product.

TP53 gene abnormalities (either point mutation or LOH) were relatively common events (60\%), but allelic loss at $R B$ gene (9\%) was infrequent in NETs of the cervix $(56,61-63)$.

\section{NEUROENDOCRINE TUMORS OF THE UTERUS}

NETs of the uterus are being extremely rare, they comprise less than $1 \%$ of all of uterine carcinomas. They originate from the endometrium as small cell (poorly differentiated neuroendocrine carcinoma, small cell type) or large cell neuroendocrine carcinoma (poorly differentiated neuroendocrine carcinoma, large cell type).

\section{A. Small Cell Carcinoma (Poorly Differentiated Neuroendocrine Carcinoma, Small Cell Type)}

To date less than 80 cases have been reported in the English literature (64). Patients' age ranges from 23 to 78 years (mean age of 60 years) and most commonly present with abnormal vaginal bleeding. Associations with paraneoplastic syndromes such as Cushing syndrome, hypoglycemia, visual disturbance and inappropriate secretion of antidiuretic hormone have been reported (39, $45,64,65)$.

Grossly, the tumor is often characterized by a bulky, exophytic or polypoid mass (Figure 4) in the endometrial cavity (65). Histologically, it resembles to small cell carcinoma of the various sites. Van Hoeven et al. proposed the following diagnostic criteria to distinguish endometrial small cell carcinoma: unequivocal evidence of endometrial origin, sheet-like growth of small and intermediate tumor cells, and positivity for at least one neuroendocrine marker by immunohistochemically (66). However, one can criticize this approach especially when dealing with a high grade carcinoma lacking immunoreactivity for chromogranin-A and synaptophysin. In such situation, positivity for other general nonspecific neuroendocrine (e.g. CD56) markers should not be used to diagnose a poorly differentiated neuroendocrine carcinoma. Of note, these tumors may develop synchronously with endometrioid adenocarcinoma, adenosquamous carcinoma or carcinosarcoma (MMMT) (Figure 5A-C). Eight of 16 small cell carcinomas were coexistent with grade I or II endometrioid adenocarcinoma in a largest series (67).

Evidence suggests that most cases present with advancedstage disease characterized by aggressive behavior and poor outcome. The 5-year survival rate varies from $17 \%$ to $64 \%$ with a median survival ranging from 12 to 21 months. Among 17 cases of stage II to IV disease with extensive follow-up, 16 patients died of disease within 24 months $(39,64,65,67)$.

\section{B. Large Cell Neuroendocrine Carcinoma (Poorly Differentiated Neuroendocrine Carcinoma, Large Cell Type)}

A total of 13 cases have been reported to date (68). They grossly and histologically resemble to their counterpart in the cervix. Tumors contain cells with large nuclei, prominent nucleoli and high mitotic index including atypical figures. Endometrioid, serous and small cell carcinoma have been reported in association with these tumors $(64,69,70)$. Similar to small cell carcinomas, LCNECs are associated with a poor prognosis.

The differential diagnosis of endometrial NETs includes secondary NETs, undifferentiated carcinoma and endometrial stromal sarcoma. Undifferentiated carcinoma is characterized by non-cohesive small to large-sized cells without any glandular differentiation. They display a relatively monotonous population of partternless cells, but they can sometimes exhibit sheet-like or nested architecture. Therefore, one can easily mistake this tumor for a NET. Moreover, undifferentiated carcinomas can also focal expression of general neuroendocrine markers, which is often regarded a phenomenon of focal divergent differentiation when the extent is less than $30 \%$ of the tumor. Nevertheless, most neuroendocrine carcinomas diffusely express two or more markers. Some authors have recommended that greater than $20 \%$ of tumor cells be positive for at least 2 neuroendocrine markers to establish the diagnosis of neuroendocrine carcinoma (71,72). Endometrial stromal tumors contain tumor cells with small, round to ovoid nuclei and scant to moderate cytoplasm. These tumors typically have a spiral arteriole-like vascular component and lack brisk mitosis. Immunohistochemically, the cells show CD10 positivity and no staining for any neuroendocrine markers. 


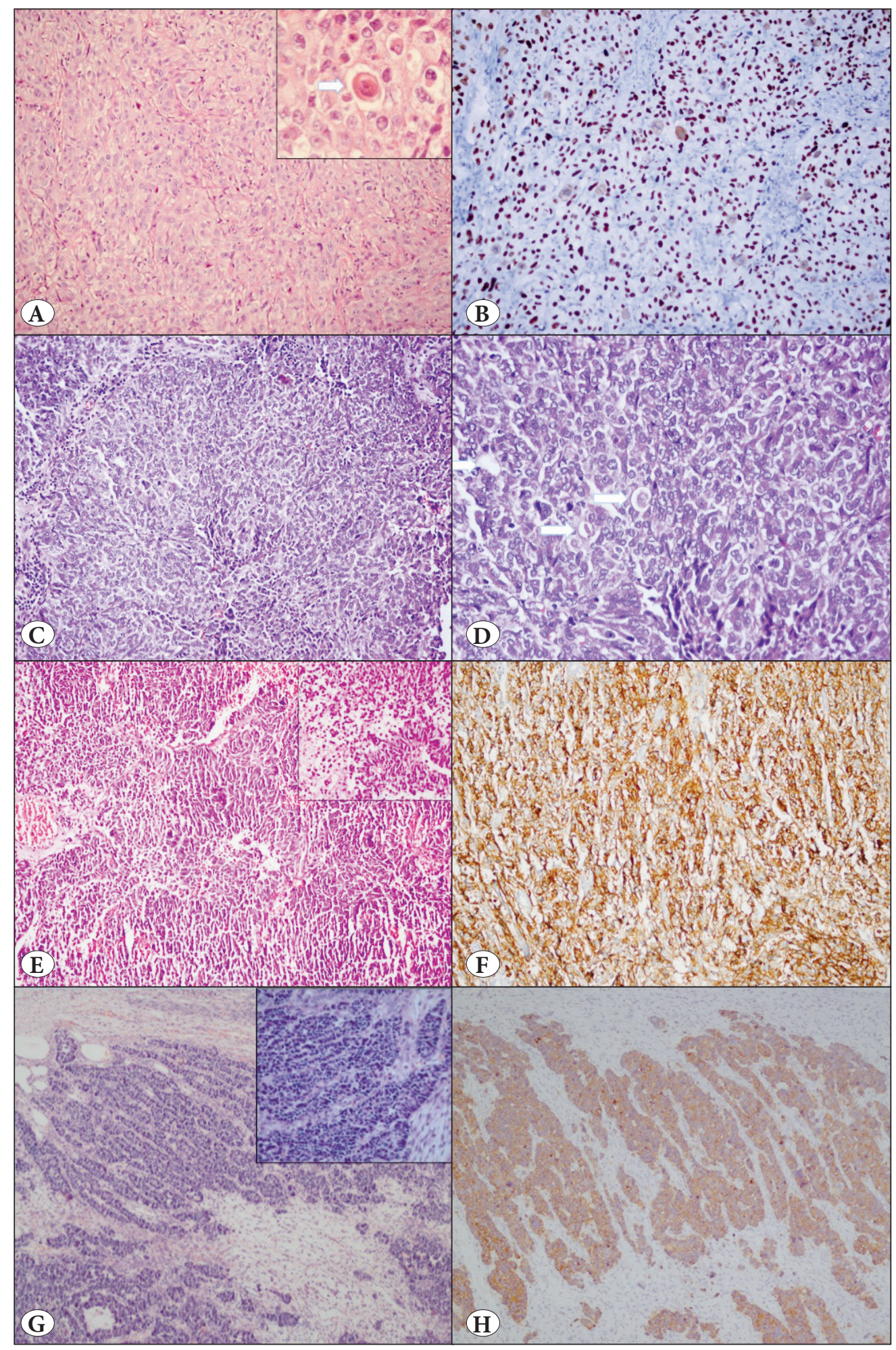

Figure 3: Comparison of common types poorly differentiated epithelial tumors and neuroendocrine carcinoma of the cervix. A) Poorly differentiated squamous carcinoma show solid pattern and there is rare single cell keratinization (arrow) (H\&E, x200 and x1000). B) Poorly differentiated squamous carcinoma diffusely positive with P63 (DAB, x200). C) Poorly differentiated adenocarcinoma show solid pattern (H\&E, x200). D) Glandular differentiation could be seen at least focally (arrows) in adenocarcinoma (H\&E, x400). E) Small cell carcinoma composes of small size oval-spindle cells with hyperchromatic nuclei and inconspicuous nucleoli (H\&E, x100 and $\mathrm{x} 400$ ). F) Small cell carcinoma diffuse positive with synaptophysin (DAB, x100). G) Large cell carcinoma comprise of large nuclei and abundant cytoplasm in fibrous stroma (H\&E, x200 and x100). H) Tumor cells diffuse positive with chromogranin (DAB, x100). 


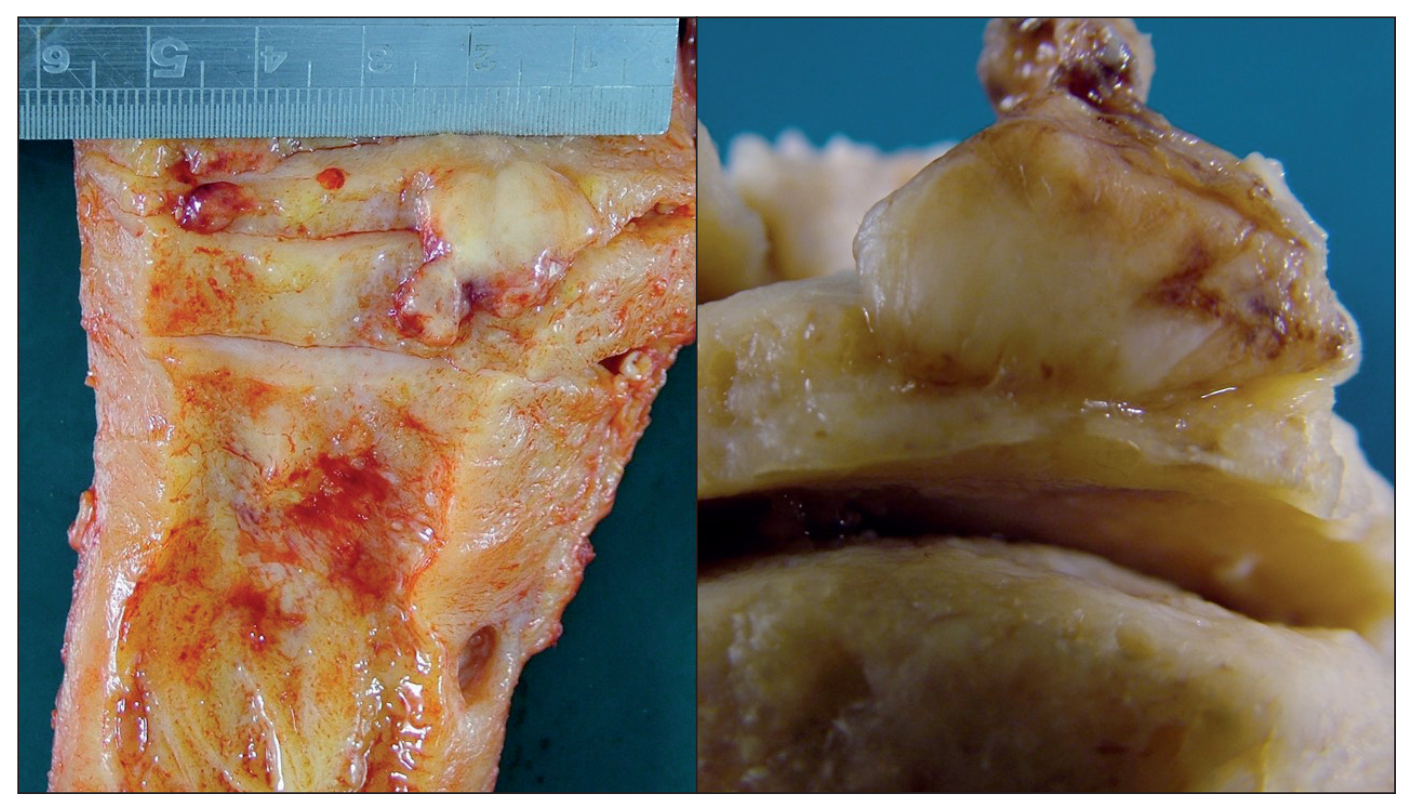

Figure 4: Gross appearance of small cell carcinoma of endometrium as a polypoid mass.
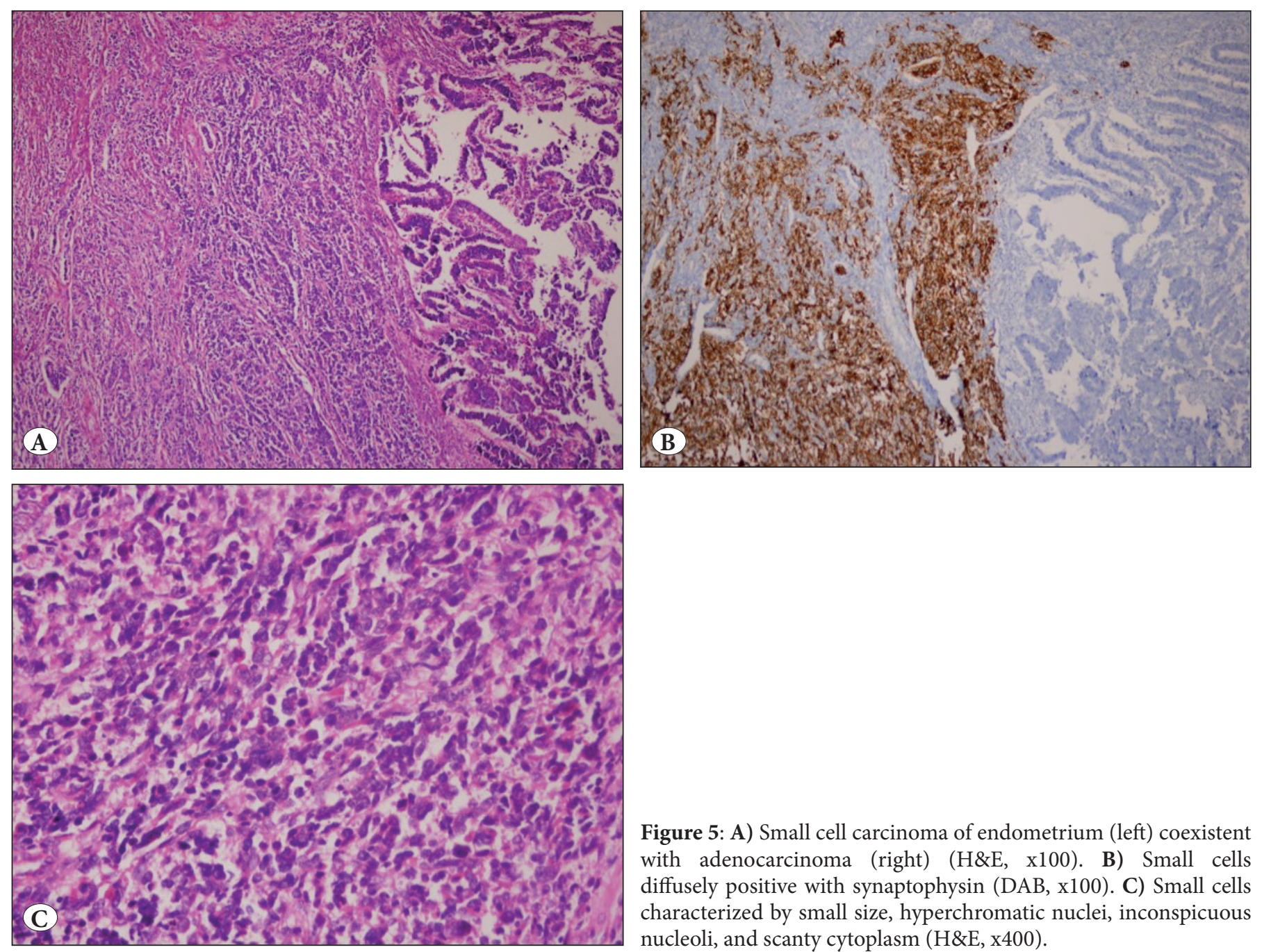

Figure 5: A) Small cell carcinoma of endometrium (left) coexistent with adenocarcinoma (right) (H\&E, x100). B) Small cells diffusely positive with synaptophysin (DAB, x100). C) Small cells characterized by small size, hyperchromatic nuclei, inconspicuous nucleoli, and scanty cytoplasm (H\&E, x400). 


\section{NEUROENDOCRINE TUMORS OF THE OVARY}

NETs of the ovary are usually seen as typical carcinoid tumor. Small cell carcinoma and non-small cell type carcinoma are rare and behave aggressively. Some of these tumors have been linked to clinical syndromes due to the secretion of peptides.

\section{A. Carcinoid Tumors (Well Differentiated Neuroendocrine Tumors)}

Primary ovarian carcinoid tumors comprise less than 0.1 $\%$ of all ovarian carcinomas and $0.5-1.7 \%$ of all carcinoid tumors. They contain well-differentiated neuroendocrine cells and usually resemble to their counterparts at other sites such as the gastrointestinal system (10). Patient's age has been reported to range from 14 to 79 years (mean age 53 years), with segregation in perimenopause or postmenopause. One-third of patients have found to develop carcinoid syndrome, which is most frequently associated with insular carcinoid. Flushing and diarrhea are the most frequent clinical manifestations of this syndrome. Five-hydroxyindole acetic acid (5-HIAA) levels in urine are frequently elevated. Carcinoid tumors may occur alone but also present as a somatic malignancy arising in an ovarian teratoma, or can be seen in association with another ovarian tumor such as mucinous tumor, Brenner tumor or SertoliLeydig cell tumor. APUD cells of the gastrointestinal and respiratory epithelium or teratomatous primitive neuroectodermal cells are possible sources of neoplastic proliferation of teratoma-associated tumors. Histologically, well differentiated NETs of the ovary can be divided into five categories: 1) insular carcinoid, 2) trabecular carcinoid, 3) strumal carcinoid, 4) goblet cell carcinoid, and 5) mixed type carcinoid $(10,21,73)$.

\section{A1. Insular Carcinoid}

This is the most common carcinoid tumor type of the ovary simulating midgut-derived carcinoids. It usually develops in a teratoma that includes respiratory or gastrointestinal system epithelium. One third of tumors have been associated associated with carcinoid syndrome, to which tumor size is closely related; two-thirds of tumors over $7 \mathrm{~cm}$ in diameter have been reported to cause carcinoid syndrome $(73,74)$.

Grossly, the tumor is usually solid, light brown to yellow in color and varies in size from microscopic disease to $20 \mathrm{~cm}$ in diameter. However, if it is related to teratoma or another tumor, it appears similar to them. Histologically, they are characterized by small acini or tubular glands arranged as small groups in fibrous stroma in which solid islands can be seen. The cells are usually uniform and polygonal in shape, with centrally located, rounded nuclei and "salt- and-pepper" chromatin. The abundant cell cytoplasm has a basophilic or amphophilic appearance (Figure 6). Dense eosinophilic secretions, which sometimes undergo psammomatous calcification, are typically found in the lumen (73-76).

Brenner tumor, granulosa cell tumor, metastatic gastrointestinal carcinoma and metastatic carcinoid tumor should be included in the differential diagnosis. Carcinoid tumors do not have the cell nest and 'coffee-bean' nuclei of the Brenner tumor. The Call-Exner bodies of the granulosa cell tumor may be mistaken for carcinoid acini but carcinoid tumors usually show a predominant acinar architecture and cells with abundant cytoplasm. Metastatic gastrointestinal tumors are usually bilateral and larger than primary carcinoid tumors. They tend to have more fibrous stroma, pleomorphism, signet-ring cells and brisk mitotic activity. If the tumor is bilateral and unaccompanied by a teratoma, metastatic well differentiated NETs should be considered.

\section{A2. Trabecular Carcinoid}

Trabecular carcinoids are similar in appearance to foregut and hindgut carcinoids. They usually arise from teratomatous elements, so the gross appearance is resembles teratomatous elements. Microscopically, the tumors are composed of ramifying cords, ribbons or trabeculae of uniform tumor cells in dense fibrous stroma. Ribbons and

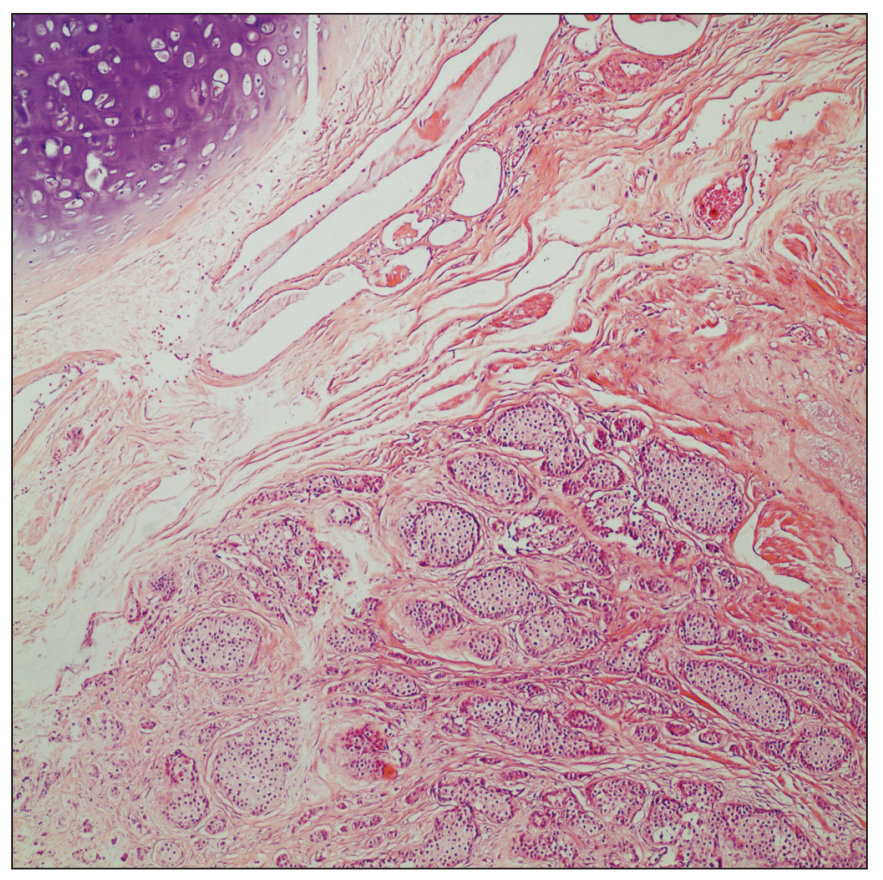

Figure 6: Insular carcinoid tumor of the ovary associated with mature teratoma (top, left field). Island of the tumor cell in fibromatous stroma (bottom, right field) (H\&E, x 40). 
cords are usually one cell layer thick but are sometimes two cell layers thick, and long axes of cells parallel each other. The nuclei are similar to the insular type $(31,74)$.

Secondary NETs and Sertoli-Leydig cell tumor are the main differential diagnoses. The prognosis is almost always favorable because several studies have reported that no patients had metastases and only one died of disease. As it would be expected, carcinoid syndrome is rarely seen in trabecular carcinoid $(31,74)$.

\section{A3. Strumal Carcinoid}

Strumal carcinoids are composed of variable proportions of thyroid tissue admixed with carcinoid tumor (Figure 7). They are frequently associated with teratoma. The carcinoid tumor is of the trabecular type. Thyroid tissue may occur with normal histology or follicular nodular disease, and caused symptoms of functioning thyroid tissue in $8 \%$ of cases $(74,77)$. The proportion of each element varies from tumor to tumor. Sometimes cell types are admixed with follicular cells. The prognosis is good in early stages but a stage IA primary ovarian stromal carcinoid was reported with multiple bone and breast metastasis (78)

\section{A4. Mucinous Carcinoid (Goblet Cell Carcinoid)}

Mucinous carcinoid is the least common type and accounts for $1.5 \%$ of cases of NETs of the female reproductive system. This is a controversial entity for some endocrine pathologists who believe that these tumors should not be

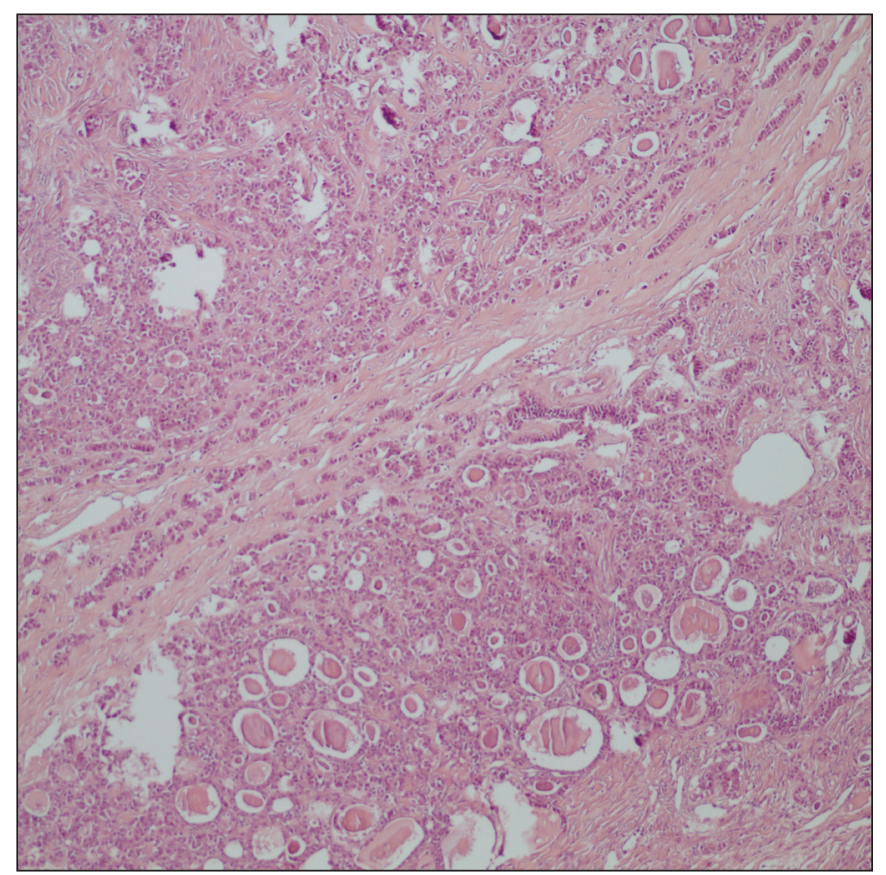

Figure 7: Strumal carcinoid of the ovary. Struma (bottom) is admixed with carcinoid tumor (top) (H\&E, x 40). classified within the spectrum of well differentiated NET. In fact, this issue has been well addressed in the $2010 \mathrm{WHO}$ classification of gastroenteropancreatic neuroendocrine tumors. Nevertheless, these neoplasms are indistinguishable from their appendiceal counterpart, which are composed of small glands lined by columnar or cuboidal cells in fibrous stroma. Some glands appear to float in pools of acellular mucin. Tumor cells may contain both neuroendocrine granules and intracytoplasmic mucin. Some cells have a goblet cell appearance (Figure 8). The cytologic atypia is minimal. Rarely, the tumor is associated with an atypical or even a carcinomatous component that is characterized by a large island of tumor cells or closely packed glands with severe cytologic atypia, increased mitosis and necrosis. The tumor is usually observed in pure form but may be associated with a teratoma or mucinous tumor (79-81).

The primary mucinous carcinoid tumor of the ovary must be differentiated from metastatic goblet cell carcinoid and mucinous tumors of the ovary. Metastatic tumors are almost always bilateral and tend to display multinodular involvement. They do not coexist with teratoma and show scattered tumor cell invasion rather than gland formation.

Primary mucinous carcinoid tumor of the ovary is slightly more aggressive than other carcinoid types of the ovary, behaving like those in the appendix since they tend to display characteristics of exocrine tumors. Most mucinous carcinoids tend to invade lymphatic and blood vessels and

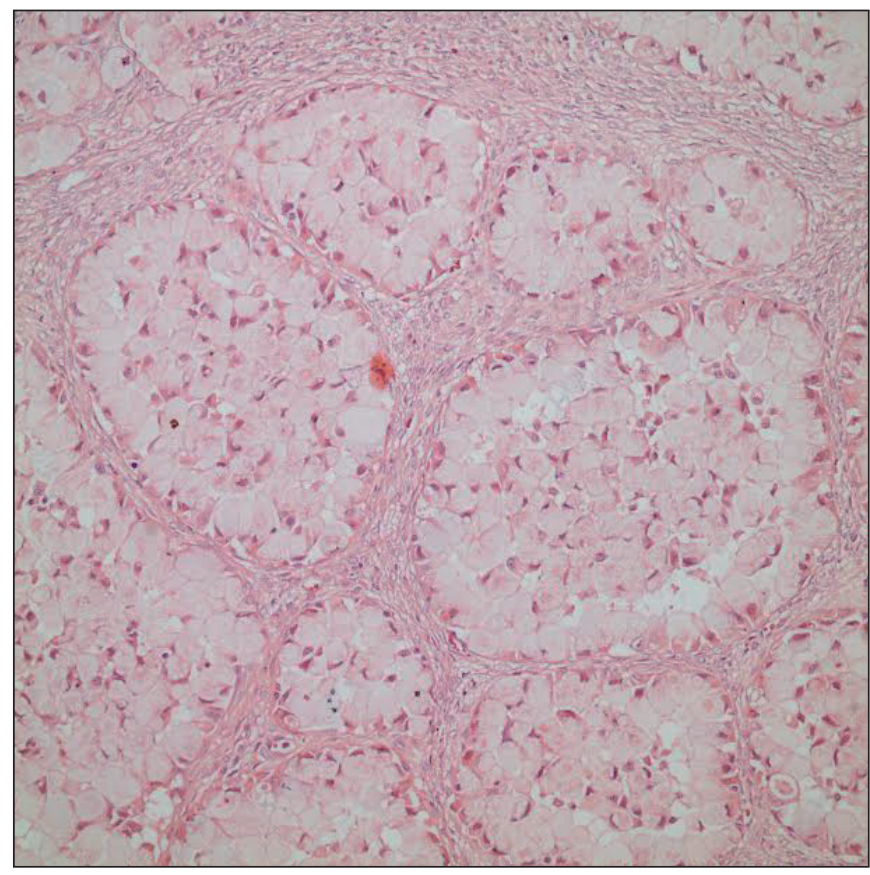

Figure 8: Mucinous carcinoid tumor of the ovary. Tumor cells have goblet cell appearance and contain mucin (H\&E, x 200). 
thus result in both regional and systemic mestastasis. It is important to emphasize that metastatic enterochromaffin cell NETs may be associated with carcinoid syndrome which often persists after the removal of the ovarian mass (79-81).

\section{A5. Mixed Type Carcinoid}

They are characterized by more than one type of carcinoid.

\section{B. Small Cell Carcinoma, Hypercalcemic Type}

This tumor is a poorly differentiated carcinoma composed primarily of small blue cells. The histogenesis of the tumor is still unknown and it is no longer considered to be a NET. However, because it shares some findings with NETs, it is included in this part of the review. These tumors are typically seen in young women (average age 24 years). In two-thirds of patients it was associated with paraneoplastic hypercalcaemia, which is related to PTHrp secretion. Most patients presented with abdominal pain or distension $(82,83)$.

Grossly, these tumors tend to be large (mean size $15 \mathrm{~cm}$ diameter) and unilateral. The external surface is lobulated and nodular. The cut surface is solid and gray-tan in color. Necrosis, hemorrhage and cystic degeneration are common. Microscopically, the tumor typically displays sheets, nests and cords. Irregularly shaped, follicle-like cystic spaces are present in $80 \%$ of cases. The cystic space contains eosinophilic fluid, and less often, basophilic material. The cells have scanty cytoplasm and small oval to round nuclei. The nucleoli are usually prominent and mitotic figures are frequent. Large cells with vesicular nuclei and abundant cytoplasm may be seen focally; rarely they are predominant and are referred to as large cell variant. These cells exhibit epithelioid or rhabdoid features (Figure 9A,B). Benign, atypical or malignant mucinous epithelial foci are present in $10 \%$ of cases $(31,82)$. Most tumors are positive for cytokeratin AE1/AE3, CD10, WT-1, calretinin and EMA. Less commonly, they are positive for vimentin, BerEP4, CD56 and synaptophysin. They tend to be negative for S100, CD99, inhibin, B72.3, desmin, chromogranin and TTF-1 $(84,85)$.

Juvenile type granulosa cell tumor must be distinguished from this neoplasm. Juvenile type granulosa cell tumor is usually seen in first decade and is associated with estrogenic manifestations. Microscopically, the tumor cells grow in a nodular pattern in fibrothecomatous stroma. Moreover, follicles are more numerous and more irregular in shape than in small cell carcinoma-HT. Juvenile type granulosa cell tumor is also typically positive for inhibin, calretinin, SF1. FOXL2, which encodes a transcription factor and related to granulosa cell function, is mostly expressed in granulosa cell tumors $(10,86)$.
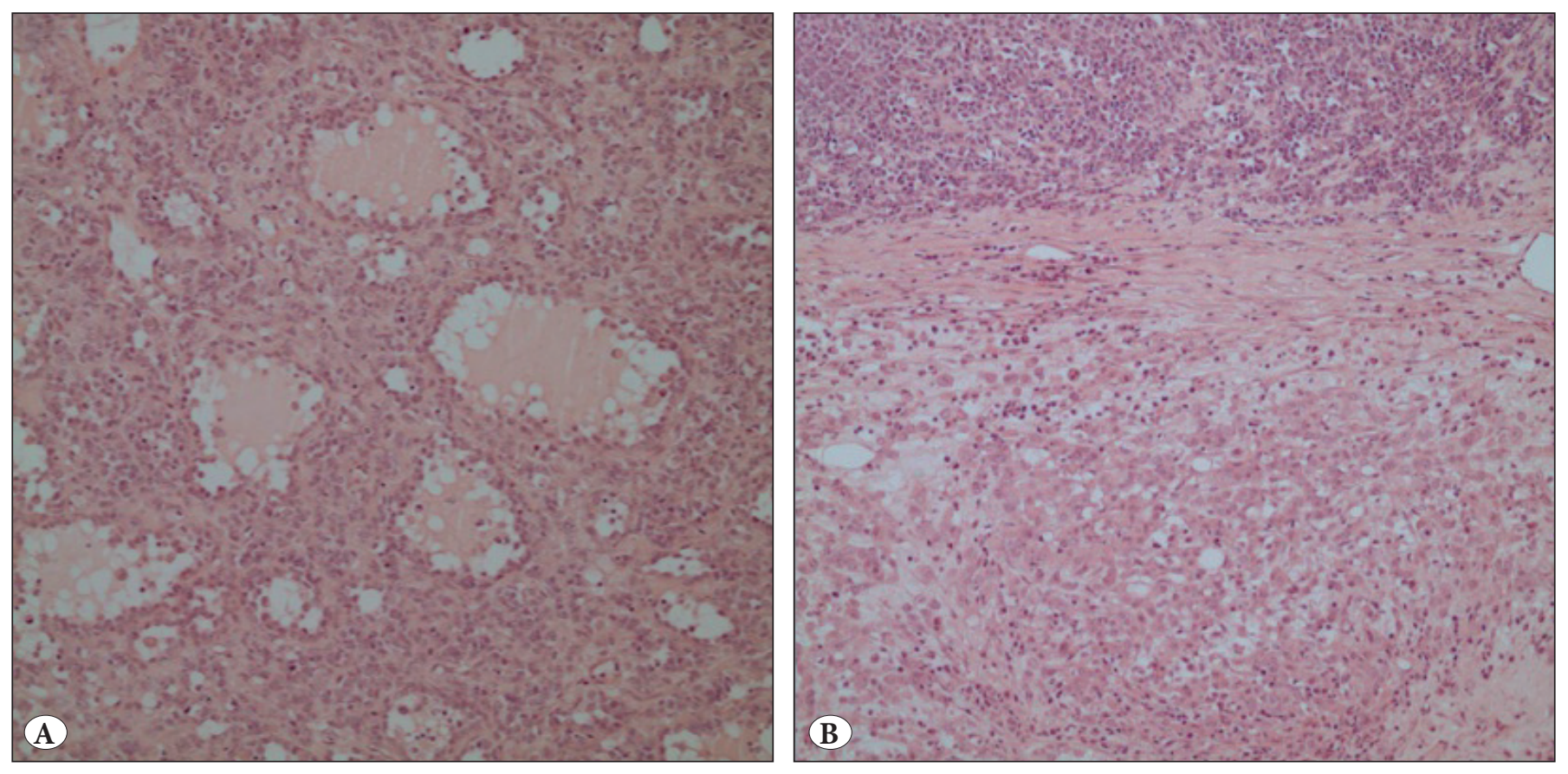

Figure 9: A) Small cell carcinoma-hypercalcemic type of the ovary. Diffusely distributed small oval to round cells and follicle-like cystic spaces (H\&E, x 200). B) Small cell component (top) juxtaposed to large cell component (bottom) that comprise of large nuclei and moderate to abundant eosinophilic cytoplasm (H\&E, x 100). 
Germline and somatic inactivating mutations in the SWI/ SNF chromatin-remodeling gene SMARCA4 identified 51 out of $57(89 \%)$ cases of small cell carcinoma-HT in three independent studies. Additionally, loss of SMARCA4 protein (also known as BRG1) demonstrated 64 out of 69 (92.8\%) cases of small cell carcinoma-HT but in only $0.4 \%$ of other primary ovarian tumors. Because of this protein highly specific for small cell carcinoma-HT, it can facilitate the differential diagnosis of this tumor as well (87-89). It is of note that, although SMARCA4 mutation is very specific for small cell carcinoma-HT, mutations in another member of the SWI/SNF complex, SMARCB1, occur in 95\% of all rhabdoid tumors (intracranial and extracranial). Small cell carcinomaHT also shares similar histopathological appearances, outcome and molecular findings of rhabdoid tumors as well. Therefore some authors proposed the reclassify this tumor and renamed as 'malignant rhabdoid tumor of the ovary' (90).

This is a highly aggressive tumor and the prognosis is poor, even for stage I tumors. Generally, at least half of the tumor has spread beyond the ovary at the time of surgery. Potentially favorable prognostic factors are age $>30$ years, normal preoperative calcium level, size $<10 \mathrm{~cm}$ and the absence of large cells $(48,82)$.

\section{Small Cell Carcinoma, Pulmonary Type}

This neoplasm is indistinguishable from pulmonary small cell carcinoma; is clinically and histologically different from small cell carcinoma-HT of the ovary. Most patients typically are in the postmenopause and present with abdominal enlargement.
Grossly, these tumors have been reported to range from 4.5 to $26 \mathrm{~cm}$ (mean $13.5 \mathrm{~cm}$ ). Microscopically, it resembles to pulmonary small cell carcinoma. The tumor is frequently associated with epithelial tumors, the most common type being endometrioid adenocarcinoma. The tumor cells have small, oval nuclei with finely granular chromatin with inconspicuous nucleolus and frequent molding by adjacent nuclei. The cytoplasm is scant. Mitoses are numerous. Immunohistochemically, the tumor usually stains for cytokeratin AE1/AE3, cytokeratin 20 (dot-like), chromogranin-A, synaptophysin, NSE and CD56. Positivity for vimentin, EMA and TTF-1 is usually variable $(21,91)$.

Metastatic pulmonary small cell carcinoma and small cell carcinoma-HT of the ovary must be included in the differential diagnosis of small cell carcinoma, pulmonary type. The presence of pulmonary symptoms and lung mass may favor a pulmonary origin. Although two tumors are same histopathologically, the identification of another ovarian surface epithelial tumor supports an ovarian primary. Immunohistochemical features may overlap, but TTF-1 positivity is more commonly seen in pulmonary metastatic tumor. Small cell carcinoma-HT occurs more frequently at a younger age than pulmonary type and is not associated with other epithelial tumors. Tumors showing follicle-like spaces and tumor cells do not have nuclear molding. TTF-1 staining is also typically negative in hypercalcemic type. Although hypercalcemia favors a small cell carcinoma-HT diagnosis, paraneoplastic manifestation may also occur in pulmonary types. Distinguishing features of both tumors are summarized in Table II.

Table II: Distinguishing features of hypercalcemic and pulmonary type small cell carcinoma of the ovary

\begin{tabular}{|c|c|c|}
\hline & Small cell carcinoma, HT & Small cell carcinoma, PT \\
\hline Age & 7 mo- $44 y$ (mean 24 y) & $28-85 y$ (mean 59y) \\
\hline Hypercalcemia & $62 \%$ & Absent \\
\hline Bilaterality & $1 \%$ & $50 \%$ \\
\hline Size & $6-26 \mathrm{~cm}($ mean $15 \mathrm{~cm})$ & $4.5-26 \mathrm{~cm}($ mean $13.5 \mathrm{~cm})$ \\
\hline \multicolumn{3}{|l|}{ Histopathological Features } \\
\hline Follicle-like spaces & $80 \%$ of cases & Absent \\
\hline Nuclear chromatin & Dispersed & Clumped \\
\hline Nuclear molding & Rare & Oftenly \\
\hline Large cell component & Rare & $40 \%$ of cases \\
\hline Nucleoli & Usually prominent & Inconspicuous \\
\hline Coexistent with Other Epithelial Tumor & Absent & Frequently (most common type endometrioid) \\
\hline \multicolumn{3}{|c|}{ Immunohistochemistry } \\
\hline TTF1 & Negative & Variable positive \\
\hline Vimentin & Variable positive & Negative \\
\hline Loss of SMARCA4 & $92.8 \%$ & Absent \\
\hline \multicolumn{3}{|l|}{ Molecular } \\
\hline SMARCA4 Mutation & $90 \%$ & Absent \\
\hline
\end{tabular}


These tumors are highly malignant and behave very aggressively, regardless of stage (91).

\section{Neuroendocrine Carcinoma, Non-Small Cell Type/ Large Cell Neuroendocrine Carcinoma}

This neoplasm is an undifferentiated carcinoma and is composed of large cells showing neuroendocrine differentiation. The patient is usually in there productive age and presents with pelvic mass-related symptoms.

The tumor is typically associated with an ovarian surface tumor such as mucinous borderline tumor, mucinous adenocarcinoma, endometrioid adenocarcinoma or teratoma. To date, only two cases have been reported to present as a pure tumor. NET component consists of medium to large cells with hyperchromatic nuclei and prominent nucleoli. Necrosis and mitotic figures are frequent. Immunohistochemically, the tumor is positive for general neuroendocrine markers $(92,93)$.

This tumor behaves highly aggressively and patients most often have a poor outcome (94).

\section{NEUROENDOCRINE TUMORS OF THE FALLOPIAN TUBE}

NETs of the fallopian tubes are extremely rare with only two cases in the literature. Both cases resemble to those of pulmonary type small cell carcinoma (95).

\section{CONFLICT OF INTEREST}

The authors have declared no conflict of interest.

\section{REFERENCES}

1. Papathomas TG, de Krijger RR, Tischler AS. Paragangliomas: Update on differential diagnostic considerations, composite tumors, and recent genetic developments. Semin Diagn Pathol. 2013; 30: 207-23

2. Mete O, Tischler AS, de Krijger R, McNicol AM, Eisenhofer G, Pacak K, Ezzat S, Asa SL. Protocol for the examination of specimens from patients with pheochromocytomas and extraadrenal paragangliomas. Arch Pathol Lab Med. 2014;138:182-8.

3. Hayashi T, Mete O. Head and neck paragangliomas: What does the pathologist need to know? Diagnostic Histopathology. 2014; 20: $316-25$

4. Schuldt M, Retamero JA, Tourné M, Nogales FF. Ovarian paraganglioma. Int J Surg Pathol. 2015; 23: 130-3.

5. van Leeuwen J, van der Putten HW, Demeyere TB, Creemers GJ, Pijnenborg JM. Paraganglioma of the uterus. A case report and review of literature. Gynecol Oncol. 2011;121:418-9.

6. Liu YQ, Yue JQ. Paraganglioma of the vulva: A case report and review of the literature. Int J Clin Exp Pathol. 2013;6:2247-50.

7. Cai T, Li Y, Jiang Q, Wang D, Huang Y. Paraganglioma of the vagina: A case report and review of the literature. Onco Targets Ther. 2014; 7: 965-8.
8. Akl MN, Naidu SG, McCullough AE, Magtibay PM. Vaginal paraganglioma presenting as a pelvic mass. Surgery. 2010;147: 169-71.

9. McCluggage WG, Young RH. Paraganglioma of the ovary: Report of three cases of a rare ovarian neoplasm, including two exhibiting inhibin positivity. Am J Surg Pathol. 2006; 30: 600-5.

10. Tavassoli FA, Devilee P. Pathology and genetics of tumors of the breast and female genital organs. Lyon: IARC Press; 2003.

11. Scully RE, Young RH, Clement PB. Atlas of tumor pathology. Tumors of the ovary, maldeveloped gonads, fallopian tube and broad ligament. 1st edition. AFIP. 1999.

12. Rutgers JL, Scully RE. Functioning ovarian tumors with peripheral steroid cell proliferation: A report of twenty-four cases. Int J Gynecol Pathol. 1986; 5: 319-37.

13. Oliva E, Young RH. Endocrine pathology of the ovary: In tribute to Robert E Scully, MD. Endocr Pathol. 2014; 25: 102-19.

14. de Palma P, Wronski M, Bifernino V, Bovani I. Krukenberg tumor in pregnancy with virilization. A case report. Eur J Gynaecol Oncol. 1995;16:59-64.

15. Kato N, Hayasaka T, Takeda J, Osakabe M, Kurachi H. Ovarian tumors with functioning stroma: A clinicopathologic study with special reference to serum estrogen level, stromal morphology, and aromatase expression. Int J Gynecol Pathol. 2013; 32: 556-61.

16. Matias-Guiu X, Prat J. Ovarian tumors with functioning stroma. An immunohistochemical study of 100 cases with human chorionic gonadotropin monoclonal and polyclonal antibodies. Cancer. 1990; 65: 2001-5.

17. Thompson MA, Adelson MD, Kaufman LM, Marshall LD, Coble DA. Aromatization of testosterone by epithelial tumor cells cultured from patients with ovarian carcinoma. Cancer Res. 1988; 48: 6491-7.

18. Clement PB, Young RH, Scully RE. Clinical syndromes associated with tumors of the female genital tract. Semin Diagn Pathol. 1991; 8: 204-33.

19. Koyama T, Togashi K, Ueda H, Kataoka ML, Fujiwara T, Kobayashi H, Kobayashi H, Fujii S, Konishi J. Paraneoplastic syndromes associated with ovarian neoplasms. Int J Clin Oncol. 2000; 5: 79-84.

20. Shanbhogue AK, Shanbhogue DK, Prasad SR, Surabhi VR, Fasih $\mathrm{N}$, Menias CO. Clinical syndromes associated with ovarian neoplasms: A comprehensive review. Radiographics. 2010; 30: 903-19.

21. Rouzbahman M, Clarke B. Neuroendocrine tumors of the gynecologic tract: Select topics. Semin Diagn Pathol. 2013; 30: 224-33.

22. Tumors of the endocrine system. In: Chu P, Weiss L, editors Modern immunohistochemistry. 2nd ed. Cambridge: Cambridge University Press; 2014. 96-132.

23. DeLellis RA. The neuroendocrine system and its tumors: An overview. Am J Clin Pathol. 2001;115 Suppl:S5-16.

24. Chu PG, Weiss LM. Keratin expression in human tissues and neoplasms. Histopathology. 2002;40:403-39.

25. Miettinen M. Keratin 20: immunohistochemical marker for gastrointestinal, urothelial and Merkel cell carcinomas. Mod Pathol. 1995; 8: 384-8. 
26. Daoud MA, Mete O, Al Habeeb A, Ghazarian D. Neuroendocrine carcinoma of the skin--an updated review. Semin Diagn Pathol. 2013; 30: 234-44.

27. LeBoit PE, Burg G, Weedon D, Sarasin A. Pathology and genetics of skin tumors. Lyon: IARC Press; 2006.

28. Buck CB, Lowy DR. Getting stronger: The relationship between a newly identified virus and Merkel cell carcinoma. J Invest Dermatol. 2009; 129: 9-11.

29. Sheikh ZA, Nair I, Vijaykumar DK, Jojo A, Nandeesh M. Neuroendocrine tumor of vulva: A case report and review of literature. J Cancer Res Ther. 2010; 6: 365-6.

30. Hierro I, Blanes A, Matilla A, Muñoz S, Vicioso L, Nogales FF. Merkel cell (neuroendocrine) carcinoma of the vulva. A case report with immunohistochemical and ultrastructural findings and review of the literature. Pathol Res Pract. 2000; 196: 503-9.

31. Robboy's Pathology of the Female Reproductive Tract. 2nd ed. Robbboy SJ, Mutter GL, Prat J, Bentley RC, Russell P, Anderson MC, editors. London: Churchill Livingstone; 2009.

32. Pulitzer MP, Amin BD, Busam KJ. Merkel cell carcinoma: Review. Adv Anat Pathol. 2009; 16:135-44.

33. Loret de Mola JR, Hudock PA, Steinetz C, Jacobs G, Macfee M, Abdul-Karim FW. Merkel cell carcinoma of the vulva. Gynecol Oncol. 1993; 51: 272-6.

34. Houben R, Schrama D, Becker JC. Molecular pathogenesis of Merkel cell carcinoma. Exp Dermatol. 2009;18:193-8.

35. Srivastava SA, Wang Y, Vallone J, Felix JC. Primary clear cell carcinoid tumors of the vulva. Am J Surg Pathol. 2012; 36: 1371-5.

36. Bing Z, Levine L, Lucci JA, Hatch SS, Eltorky MA. Primary small cell neuroendocrine carcinoma of the vagina: A clinicopathologic study. Arch Pathol Lab Med 2004;128:857-62.

37. Kaminski JM, Anderson PR, Han AC, Mitra RK, Rosenblum NG, Edelson MI. Primary small cell carcinoma of the vagina. Gynecol Oncol. 2003; 88: 451-5.

38. Colleran KM, Burge MR, Crooks LA, Dorin RI. Small cell carcinoma of the vagina causing Cushing's syndrome by ectopic production and secretion of ACTH: A case report. Gynecol Oncol. 1997; 65: 526-9.

39. Crowder S, Tuller E. Small cell carcinoma of the female genital tract. Semin Oncol. 2007; 34: 57-63.

40. Hayashi M, Mori Y, Takagi Y, Hoshimoto K, Ohkura T. Primary small cell neuroendocrine carcinoma of the vagina. Marked effect of combination chemotherapy: A case report. Oncology. 2000; 58: 300-4.

41. Mannion C, Park WS, Man YG, Zhuang Z, Albores-Saavedra J, Tavassoli FA. Endocrine tumors of the cervix: Morphologic assessment, expression of human papillomavirus, and evaluation for loss of heterozygosity on 1p,3p, 11q, and 17p. Cancer. 1998; 83: $1391-400$.

42. Gilks CB, Young RH, Gersell DJ, Clement PB. Large cell neuroendocrine [corrected] carcinoma of the uterine cervix: A clinicopathologic study of 12 cases. Am J Surg Pathol. 1997; 21: 905-14.
43. Ambros RA, Park JS, Shah KV, Kurman RJ. Evaluation of histologic, morphometric, and immunohistochemical criteria in the differential diagnosis of small cell carcinomas of the cervix with particular reference to human papillomavirus types 16 and 18. Mod Pathol. 1991; 4: 586-93.

44. Stoler MH, Mills SE, Gersell DJ, Walker AN. Small-cell neuroendocrine carcinoma of the cervix. A human papillomavirus type 18-associated cancer. Am J Surg Pathol. 1991; 15: 28-32.

45. Albores-Saavedra J, Gersell D, Gilks CB, Henson DE, Lindberg G, Santiago H, Scully RE, Silva E, Sobin LH, Tavassoli FJ, Travis WD, Woodruff JM. Terminology of endocrine tumors of the uterine cervix: Results of a workshop sponsored by the College of American Pathologists and the National Cancer Institute. Arch Pathol Lab Med. 1997; 121: 34-9.

46. Yoshida Y, Sato K, Katayama K, Yamaguchi A, Imamura Y, Kotsuji F. Atypical metastatic carcinoid of the uterine cervix and review of the literature. J Obstet Gynaecol Res. 2011; 37: 636-40.

47. Wang KL, Yang YC, Wang TY, Chen JR, Chen TC, Chen HS, $\mathrm{Su}$ TH, Wang KG. Neuroendocrine carcinoma of the uterine cervix: A clinicopathologic retrospective study of 31 cases with prognostic implications. J Chemother. 2006; 18: 209-16.

48. Nucci MR, Oliva E. Gynecologic pathology: A volume in the series foundations in diagnostic pathology. Edinburgh: Churchill Livingstone/Elsevier; 2009.

49. Abeler VM, Holm R, Nesland JM, Kjørstad KE. Small cell carcinoma of the cervix. A clinicopathologic study of 26 patients. Cancer. 1994; 73(3): 672-7.

50. Seckl MJ, Mulholland PJ, Bishop AE, Teale JD, Hales CN, Glaser M, Watkins S, Seckl JR. Hypoglycemia due to an insulin-secreting small-cell carcinoma of the cervix. N Engl J Med. 1999; 341: 7336.

51. Alphandery C, Dagrada G, Frattini M, Perrone F, Pilotti S. Neuroendocrine small cell carcinoma of the cervix associated with endocervical adenocarcinoma: A case report. Acta Cytol. 2007; 51: 589-93.

52. Viswanathan AN, Deavers MT, Jhingran A, Ramirez PT, Levenback C, Eifel PJ. Small cell neuroendocrine carcinoma of the cervix: Outcome and patterns of recurrence. Gynecol Oncol. 2004; 93: 27-33.

53. Gersell DJ, Mazoujian G, Mutch DG, Rudloff MA. Small-cell undifferentiated carcinoma of the cervix. A clinicopathologic, ultrastructural, and immunocytochemical study of 15 cases. Am J Surg Pathol. 1988; 12: 684-98.

54. Albores-Saavedra J, Latif S, Carrick KS, Alvarado-Cabrero I, Fowler MR. CD56 reactivity in small cell carcinoma of the uterine cervix. Int J Gynecol Pathol. 2005; 24: 113-7.

55. Straughn JM Jr, Richter HE, Conner MG, Meleth S, Barnes MN.Predictors of outcome in small cell carcinoma of the cervix-a case series. Gynecol Oncol. 2001; 83: 216-20.

56. Ishida GM, Kato N, Hayasaka T, Saito M, Kobayashi H, Katayama Y, Sasou S, Yaegashi N, Kurachi H, Motoyama T. Small cell neuroendocrine carcinomas of the uterine cervix: A histological, immunohistochemical, and molecular genetic study. Int J Gynecol Pathol. 2004; 23: 366-72. 
57. Conner MG, Richter H, Moran CA, Hameed A, Albores-Saavedra J. Small cell carcinoma of the cervix: A clinicopathologic and immunohistochemical study of 23 cases. Ann Diagn Pathol. 2002; 6: 345-8.

58. Hoskins PJ, Swenerton KD, Pike JA, Lim P, Aquino-Parsons C, Wong F, Lee N. Small-cell carcinoma of the cervix: Fourteen years of experience at a single institution using a combined-modality regimen of involved-field irradiation and platinum-based combination chemotherapy. J Clin Oncol. 2003; 21: 3495-501.

59. Krivak TC, McBroom JW, Sundborg MJ, Crothers B, Parker MF. Large cell neuroendocrine cervical carcinoma: A report of two cases and review of the literature. Gynecol Oncol. 2001; 82: 18791.

60. Sato Y, Shimamoto T, Amada S, Asada Y, Hayashi T. Large cell neuroendocrine carcinoma of the uterine cervix: A clinicopathological study of six cases. Int J Gynecol Pathol. 2003; 22: 226-30

61. Wistuba II, Thomas B, Behrens C, Onuki N, Lindberg G, AlboresSaavedra J, Gazdar AF. Molecular abnormalities associated with endocrine tumors of the uterine cervix. Gynecol Oncol. 1999; 72: 3-9.

62. Atienza-Amores M, Guerini-Rocco E, Soslow RA, Park KJ, Weigelt B. Small cell carcinoma of the gynecologic tract: A multifaceted spectrum of lesions. Gynecol Oncol. 2014; 134: 4108.

63. Mannion C, Park WS, Man YG, Zhuang Z, Albores-Saavedra J, Tavassoli FA. Endocrine tumors of the cervix: Morphologic assessment, expression of human papillomavirus, and evaluation for loss of heterozygosity on 1p, 3p, 11q, and 17p. Cancer 1998; 83:1391-400.

64. Albores-Saavedra J, Martinez-Benitez B, Luevano E. Small cell carcinomas and large cell neuroendocrine carcinomas of the endometrium and cervix: Polypoid tumors and those arising in polyps may have a favorable prognosis. Int J Gynecol Pathol. 2008; 27: 333-9.

65. Katahira A, Akahira J, Niikura H, Ito K, Moriya T, Matsuzawa S, Makinoda S, Oda T, Fujiwara K, Yaegashi N. Small cell carcinoma of the endometrium: Report of three cases and literature review. Int J Gynecol Cancer. 2004; 14: 1018-23.

66. Van Hoeven KH, Hudock JA, Woodruff JM, Suhrland MJ. Small cell carcinoma of the endometrium. Int J Gynecol Pathol 1995;14:21-9.

67. Huntsman DG, Clement PB, Gilks CB, Scully RE. Small-cell carcinoma of the endometrium. A clinicopathological study of sixteen cases. Am J Surg Pathol. 1994; 18(4): 364-75.

68. Nguyen ML, Han L, Minors AM, Bentley-Hibbert S, Pradhan TS, Pua TL, Tedjarati SS. Rare large cell neuroendocrine tumor of the endometrium: A case report and review of the literature. Int J Surg Case Rep. 2013; 4: 651-5.

69. Mulvany NJ, Allen DG. Combined large cell neuroendocrine and endometrioid carcinoma of the endometrium. Int J Gynecol Pathol. 2008; 27: 49-57.

70. Posligua L, Malpica A, Liu J, Brown J, Deavers MT. Combined large cell neuroendocrine carcinoma and papillary serous carcinoma of the endometrium with pagetoid spread. Arch Pathol Lab Med. 2008; 132: 1821-4.
71. Bartosch C, Manuel Lopes J, Oliva E. Endometrial carcinomas: A review emphasizing overlapping and distinctive morphological and immunohistochemical features. Adv Anat Pathol. 2011; 18: 415-37.

72. Rabban JT, Soslow RA, Zaloudek CZ. Immunohistology of the female genital tract. In: Dabbs DJ, editors. Diagnostic immunohistochemistry - Theranostic and genomic applications. Philadelphia: Saunders-Elsevier; 2010:690-762.

73. Robboy SJ, Norris HJ, Scully RE. Insular carcinoid primary in the ovary. A clinicopathologic analysis of 48 cases. Cancer. 1975; 36: 404-18.

74. Soga J, Osaka M, Yakuwa Y. Carcinoids of the ovary: An analysis of 329 reported cases. J Exp Clin Cancer Res. 2000; 19: 271-80.

75. Díaz-Montes TP, Rosenthal LE, Bristow RE, Grumbine FC. Primary insular carcinoid of the ovary. Gynecol Oncol. 2006; 101: 175-8.

76. Lagoudianakis EE, Markogiannakis H, Karantzikos G, Papadima A, Alevizos L, Manouras A. Primary insular carcinoid of the ovary. Eur J Gynaecol Oncol. 2008; 29: 554-5.

77. Robboy SJ, Scully RE. Strumal carcinoid of the ovary: An analysis of 50 cases of a distinctive tumor composed of thyroid tissue and carcinoid. Cancer. 1980; 46: 2019-34.

78. Kurabayashi T, Minamikawa T, Nishijima S, Tsuneki I, Tamura M, Yanase T, Hashidate H, Shibuya H, Motoyama T. Primary strumal carcinoid tumor of the ovary with multiple bone and breast metastases. J Obstet Gynaecol Res. 2010; 36: 567-71.

79. Baker PM, Oliva E, Young RH, Talerman A, Scully RE. Ovarian mucinous carcinoids including some with a carcinomatous component: A report of 17 cases. Am J Surg Pathol. 2001; 25: 55768.

80. Buis CC, van Doorn HC, Dinjens WN, Ewing PC. Mucinous carcinoid of the ovary: report of a case with metastasis in the contralateral ovary after ten years. Rare Tumors. 2010 Sep 30;2:e39.

81. Wolpert HR, Fuller AF, Bell DA. Primary mucinous carcinoid tumor of the ovary. A case report. Int J Gynecol Pathol. 1989; 8:156-62.

82. Young RH, Oliva E, Scully RE. Small cell carcinoma of the ovary, hypercalcemic type. A clinicopathological analysis of 150 cases. Am J Surg Pathol. 1994; 18: 1102-16.

83. Matias-Guiu X, Prat J, Young RH, Capen CC, Rosol TJ, Delellis RA, Scully RE. Human parathyroid hormone-related protein in ovarian small cell carcinoma. An immunohistochemical study. Cancer. 1994; 73: 1878-81.

84. McCluggage WG, Oliva E, Connolly LE, McBride HA, Young RH. An immunohistochemical analysis of ovarian small cell carcinoma of hypercalcemic type. Int J Gynecol Pathol 2004; 23:330-6.

85. Aguirre P, Thor AD, Scully RE. Ovarian small cell carcinoma. Histogenetic considerations based on immunohistochemical and other findings. Am J Clin Pathol. 1989; 92:140-9.

86. Al-Agha OM, Huwait HF, Chow C, Yang W, Senz J, Kalloger SE, Huntsman DG, Young RH, Gilks CB. FOXL2 is a sensitive and specific marker for sex cord-stromal tumors of the ovary. Am J Surg Pathol. 2011;35: 484-94. 
87. Witkowski L, Carrot-Zhang J, Albrecht S, Fahiminiya S, Hamel N, Tomiak E, Grynspan D, Saloustros E, Nadaf J, Rivera B, Gilpin C, Castellsagué E, Silva-Smith R, Plourde F, Wu M, Saskin A, Arseneault M, Karabakhtsian RG, Reilly EA, Ueland FR, Margiolaki A, Pavlakis K, Castellino SM, Lamovec J, Mackay HJ, Roth LM, Ulbright TM, Bender TA, Georgoulias V, Longy M, Berchuck A, Tischkowitz M, Nagel I, Siebert R, Stewart CJ, Arseneau J, McCluggage WG, Clarke BA, Riazalhosseini Y, Hasselblatt M, Majewski J, Foulkes WD. Germline and somatic SMARCA4 mutations characterize small cell carcinoma of the ovary, hypercalcemic type. Nat Genet. 2014; 46: 438-43.

88. Jelinic P, Mueller JJ, Olvera N, Dao F, Scott SN, Shah R, Gao J, Schultz N, Gonen M, Soslow RA, Berger MF, Levine DA. Recurrent SMARCA4 mutations in small cell carcinoma of the ovary. Nat Genet. 2014; 46: 424-6.

89. Ramos P, Karnezis AN, Craig DW, Sekulic A, Russell ML, Hendricks WP, Corneveaux JJ, Barrett MT, Shumansky K, Yang Y, Shah SP, Prentice LM, Marra MA, Kiefer J, Zismann VL, McEachron TA, Salhia B, Prat J, D’Angelo E, Clarke BA, Pressey JG, Farley JH, Anthony SP, Roden RB, Cunliffe HE, Huntsman DG, Trent JM. Small cell carcinoma of the ovary, hypercalcemic type, displays frequent inactivating germline and somatic mutations in SMARCA4. Nat Genet. 2014; 46: 427-9.
90. Foulkes WD, Clarke BA, Hasselblatt M, Majewski J, Albrecht S, McCluggage WG. No small surprise - small cell carcinoma of the ovary, hypercalcaemic type, is a malignant rhabdoid tumour. J Pathol. 2014; 233: 209-14.

91.Eichhorn JH, Young RH, Scully RE. Primary ovarian small cell carcino- ma of pulmonary type. A clinicopathologic, immunohistologic, and flow cytometric analysis of 11 cases. Am J Surg Pathol. 1992; 16: 926-38.

92. Eichhorn JH, Lawrence WD, Young RH, Scully RE. Ovarian neuroendocrine carcinomas of non-small-cell type associated with surface epithelial adenocarcinomas. A study of five cases and review of the literature. Int J Gynecol Pathol. 1996; 15: 303-14.

93. Veras E, Deavers MT, Silva EG, Malpica A. Ovarian nonsmall cell neuroendocrine carcinoma: A clinicopathologic and immunohistochemical study of 11 cases. Am J Surg Pathol. 2007; 31: 774-82.

94. Chen KT. Composite large-cell neuroendocrine carcinoma and surface epithelial-stromal neoplasm of the ovary. Int J Surg Pathol. 2000; 8: 169-74.

95. Alvarado-Cabrero I, Young RH, Vamvakas EC, Scully RE. Carcinoma of the fallopian tube: A clinicopathological study of 105 cases with observations on staging and prognostic factors. Gynecol Oncol. 1999; 72: 367-79. 